\title{
IMPACT OF EU REGIONAL POLICY ON THE DEVELOPMENT OF CROSS-BORDER COOPERATION OF AP VOJVODINA AND POSSIBILITIES OF USE OF THE PRE-ACCESSION ASSISTANCE
}

\author{
Milan Počuča ${ }^{1}$, Jelena Matijašević - Obradovićn ${ }^{2}$ Darko Golić3 \\ *Corresponding author E-mail: pocucabmilan@gmail.com
}

\begin{abstract}
A R T I C L E I N F O
A B S T R A C T

Original Article

The paper analyses the practical application of pre-

Received: 25 April 2018 accession funds in the function of regional development, in

Accepted: 10 September 2018

doi:10.5937/ekoPolj1803045P

UDC 331.1(497.13)(4-672EU) the case of development of cross-border cooperation of AP Vojvodina in the period 2007-2013. The results obtained point to the fact that the districts in AP Vojvodina are with the most attracted assets and applicants in the period of IPA programme implementation: South Bačka district (cross-

Keywords:

EU regional policy, $A P$ border cooperation - Hungary and Serbia) and South Banat district (cross-border cooperation - Romania and Serbia); Vojvodina, IPA programme, IPA II programme, cross-border cooperation that most assets and most projects were realised in crossborder cooperation between Hungary and Serbia; that the participation of realised assets in AP Vojvodina are the following: Hungary - Serbia: 27,35\%; Romania - Serbia: 12,98\%; Croatia - Serbia: 1,64\%; Bosnia and Herzegovina JEL: R58, P25, O18, F63, F15 - Serbia: 0,21\%. Within the conclusion, an overview was made of the possibilities of the use of IPA II programme for the period 2014-2020 by AP Vojvodina.
\end{abstract}

(C) 2018 EA. All rights reserved.

\section{Introduction}

The European Union's regional policy, according to the prevailing opinion, is one of the most important common EU policies. In the context of the argumentation of this paragraph, primarily stated is the focus of the objectives of the EU regional policy towards cohesion and solidarity with the aim of improvement of economic state of the poorer EU Member States, as well as the commitment to the development of innovation and competitiveness, modernisation, improvement of educational activities,

1 Milan Počuča, PhD, Full professor, Faculty of Law for Commerce and Judiciary in Novi Sad, Geri Karolja Street no. 1, Novi Sad 21 000, Serbia, Phone: +381 63 224740, E-mail: pocucabmilan@gmail.com

2 Jelena Matijašević-Obradović, $\mathrm{PhD}$, Associate professor, Faculty of Law for Commerce and Judiciary in Novi Sad, Geri Karolja Street no. 1, Novi Sad 21 000, Serbia, Phone: +381 60065 2249, E-mail: jela_sup@yahoo.com

3 Darko Golić, PhD, Assistant professor, Faculty of Law for Commerce and Judiciary in Novi Sad, Geri Karolja Street no. 1, Novi Sad 21 000, Serbia, Phone: +381 69 3312633; E-mail: g.darko83@gmail.com

http://ea.bg.ac.rs 
environmental protection and other strategically important areas. In other words, the definition of EU regional policy is the reduction of economic and social differences between the EU Member States by systematic and planned incentives for regional development, in continuity.

In the context of the above, certain authors point out that, when considering the positive aspects of the implementation of the EU regional policy concept "it should be borne in mind that it is not only about the regional development in the narrow sense of the word, but also about the effort to achieve the a connection at the European Union level by reducing the existing differences in the development level between its regions" (Mirić, 2009). Referring to this view, it is necessary to make a quick overview of the concepts of regionalism and regionalisation and to point out to the ambiguity and the important elements of distinction of both concepts in relation to the concept of EU regional policy.

Citing numerous manifestations of regionalisation, with different political, administrative, legal or economic characteristics, and the aspect of decentralisation as the basic characteristic of regionalism as a political concept and projection, Golić and Počuča (2017) emphasize the fact that political-territorial autonomy, as one of its manifestations, means the specificity of a certain part of the territory valued through its own (mainly asymmetrical) jurisdictions, revenues and organisation. In theory, the concept of regionalism, as a political projections or a programme, is defined as "advocating for such forms of government that allow and encourage the development of culture and institutions within a region with special jurisdiction and that include the transfer of essential political and legal competencies to regional authorities, with less than full sovereignty, but more than mere administrative functions" (Komšić, 2007). In this context, Kačar et al. (2016) state that the development of a narrower territorial entity is a complex issue, which, in addition to economic development policy, also includes issues in the field of agriculture, local infrastructure development policy, as a necessary ambience of local economic development, as well as a wide range of civic initiatives, which also imply numerous positive effects in the field of local community development.

Unlike regionalism, under regionalisation, as a kind of methodological approach and distribution system of competencies and relations in a specific constitutional or administrative system, which aims to establish a special level of government - as a higher level of self-government (e.g. France, Poland, Sweden, the Netherlands) or territorial autonomy throughout the territory (Spain, Italy - the so-called political regionalisation) implies the process of creation or formation of lower administrative-territorial units within the state and transferring a part of state power to these units, where these administrative-territorial units represent the central level of government, between the central government and the municipalities (Vuković, Jovanović, Grubišić, 2012). In a wider sense, the organisation of central authorities at a regional level (deconcentration), economic regionalisation (statistical regions) or inter-municipal regional association, as forms of functional regionalisation, can also be considered as regionalisation. Bearing in mind comparative solutions, it is not possible to determine the existence of a model or standard of organisation of jobs of regional character - regionalisation. 
In the context of the distinction between regionalism and regionalisation on the one hand and the concept of regional policy of the European Union on the other hand, it is necessary to emphasise that regionalism and regionalisation are the choice of each individual national regional policy, with reflections primarily at the national level, while the regional policy of the European Union is directed at the supranational level elements, on the continuous systematic and planned incentives for regional development, which has already been mentioned previously.

In the context of the prevalent peculiarities of EU regional policy, the paper will first make a theoretical overview of the objectives and importance of EU regional policy, as well as of the financial instruments for its realisation, and then, within the research work and using the relevant methodology, it shall analyse the practical application of pre-accession funds in the function of regional development, in the case of the development of cross-border cooperation of AP Vojvodina in the period 2007-2013, i.e. in the IPA programme implementation period. Within the conclusion, an overview shall be made of the possibilities of the use of pre-accession assistance for the period 20142020, within the IPA II programme.

\section{Literature review}

The regional policy of the European Union is also called the EU investment policy, bearing in mind that it represents the basic, i.e. main investment instrument in the process of encouraging regional development and financing of all vital components of the mentioned process. EU regional policy is also called the EU cohesion policy, bearing in mind that its overall objective is to strengthen economic, social and territorial cohesion in the regions.

According to the relevant views, in practice this means that economic and social cohesion involves the processes of stimulating competitive economic growth in the regions, respecting the principles of environmental protection, better employment opportunities, and, in principle, better living conditions, while territorial cohesion involves connecting the region with the aim of innovative and mutually harmonised solving of all concrete and potential challenges, which in principle supports both the regions and the European Union in general (European Commission, 2014).

In theory, in the domain of the purpose and justification of the application of the regional policy of the European Union, it is often stated that, from the very beginning, cohesion policy had a dual role in European policies, which in fact means that it should simultaneously promote regional development, but also be a sort or a source of additional funds for the Member States (Međak, Majstorović, 2004).

EU cohesion policy objectives for the period 2014-2020 were presented in the Strategy for smart, sustainable and inclusive growth, called Europe 2020, which was adopted in 2010 (Europe 2020, 2010). 
Analysing the priorities of the Europe 2020 Strategy, Kronja highlights the following objectives of the European Union regional policy: smart growth - development of knowledge-based economy and innovation (scientific and technological research and development, innovation, education and digital society); sustainable growth - simultaneous encouraging of competitiveness and production that is more resource-efficient; inclusive growth - better participation in the labour market, fight against poverty and social cohesion (whereby the basis for the strategy was: "the economic crisis exit plan; confronting global challenges; continuity in implementation - continuation of the Lisbon Strategy, financial support strengthening; better coordination with other EU policies, better division of labour between EU institutions and Member States, new, more efficient mechanisms for implementation and strengthening of competitiveness at the European level. The basic interrelated elements of the new strategy are: three related priority areas, five main quantitative objectives, seven leading initiatives, ten integrated guidelines, a new system of European economic governance, stronger instruments for strategy implementation monitoring, a clear division of responsibilities, relevance for the countries that want to become EU members") (Kronja, 2015).

According to the EU cohesion policy, each member state has, within the framework of their national regional policy, defined quantitative, interrelated and conditioned objectives that they want to achieve for a period of ten years. With the aim of achieving the objectives of the national regional policies, the Europe 2020 Strategy has defined seven specific initiatives within the above mentioned three general objectives of the Strategy, while the EU Council has adopted ten integrated guidelines to ensure the implementation of the objectives of the national regional policies by 2020 (Strategy 2020, 2010).

In line with the presented objectives of the regional policy of the European Union, the theory states that the EU cohesion concept in fact implies "the preparation and implementation of programmes and projects financed primarily from the EU cohesion and structural funds, and it is therefore necessary to emphasise that preparations for the management of this policy in fact involve the preparation for the management of EU funds that are focused on the implementation of strategic plans and priorities defined at both the EU and member state levels" (Mirić, 2014).

When considering the available funds of the European Union, it is necessary to start from the fact that there are three types of EU funds: funds for assistance to EU Member States (the so-called European Structural and Investment Funds), funds to help the candidate countries with integration into the European Union (the so-called pre-accession assistance) and funds for assistance to third countries (e.g. CARDS, TACIS) (Algebra University College, 2017).

Funds for assistance to EU Member States are made up of European Structural and Investment Funds, which include the following funds: European Regional Development Fund - ERDF, European Social Fund - ESF, Cohesion Fund - CF, European Agricultural Fund for Rural Development - EAFRD I European Maritime and Fisheries Fund - EMFF (European Commission, 2017, European Commission, 2011). 
Funds for assistance to candidate countries with integration into the European Union (the so-called pre-accession assistance) consisted of a series of programs, up until 2007. As stated in the document called AP Vojvodina Development Program 20142020, the European Union has over the course of time developed a whole range of external assistance programmes, of which Serbia has used the CARDS (Community Assistance for Reconstruction, Development and Stabilisation) instrument in the amount of approximately 1.4 billion EUR, in the period 2000-2006. In addition to CARDS, the following financial instruments of the European Union were also available to other countries in the accession process: Phare (Pologne et Hongrie - Aide a Restructuration Economique), ISPA (Instrument for Structural Policies for pre-Accession), SAPARD (Special pre-Accession Assistance for Agriculture and Rural Development) (Group of authors, 2016).

All of the aforementioned programs were replaced in 2007 by one Instrument for Pre-Accession Assistance - IPA programme. Namely, a significant feature of the fifth phase in the regional policy of the European Union (2007-2013) was the unification of pre-accession instruments for assistance to potential member countries. By the European Council Regulation no. 1085/2006, dated 17 July 2006, which entered into force on 1 January 2007, all the previous and previously mentioned instruments have been replaced by an Instrument for Pre-Accession Assistance (IPA), which consists of 5 components and provides a framework for assisting candidate and potential candidate countries (Regional Development, 2017). The aforementioned Framework Agreement in principle defines the general rules for IPA financial assistance and thus defines the direction of work of state authorities at the central and provincial level, as well as of local self-government units. In principle, the purpose of the IPA programme implementation is to prepare the countries for the use of the Structural and Cohesion Funds after gaining membership in the European Union.

The five components of the IPA programme under which assets were allocated in the period up to 2013 are: transition and institution building support, cross-border cooperation, regional development, human resources development and rural development.

The aim of the first IPA component is to provide support in the process of joining the European Union. This component allows a country that is a potential candidate for EU membership to participate in Community Programs and the work of EU agencies. The second IPA component is also targeted at countries in the process of EU accession. The goal of the second IPA component is primarily to encourage further cross-border cooperation with Western Balkan countries, as well as candidates and potential candidates for EU membership.

The basic precondition for using third and fourth IPA components is to gain the status of a candidate for membership in the European Union and to accredit a decentralized EU funds management system. Component III supports infrastructure projects in the sectors of environment, regional competitiveness and transport, while Component IV is a program framework for the use of funds in the sector of employment, education, 
social inclusion and integration, as well as strengthening the institutional capacity and efficiency of public administration and public services.

Through the fifth IPA Component, the European Union provides to candidate countries with support in the process of adjusting the agricultural sector and rural areas, harmonizing national legislation and managing the Common Agricultural Policy. This component is only intended for candidate countries.

Having in mind the research subject in the paper, it is necessary to pint out the basic peculiarities of the second component of the IPA programme - cross-border cooperation.

Namely, cross-border cooperation as the second component of the IPA programme, applied in the period 2007-2013, consisted of two parts. The first part, or the whole, concerned the assets allocated for bilateral cross-border programmes with the neighbouring Member States, while the other whole referred to the assets for the programmes with Serbia, Bosnia and Herzegovina and Montenegro. As current publications used to state, "the usual areas that were financed in cross-border cooperation were tourism, environmental protection, entrepreneurship promotion, etc. IPA cross-border cooperation in the mentioned period included two transnational programs as well, which could involve certain regions. It is the IPA Adriatic Programme and the South East Europe Programme" (Algebra University College, 2017).

In addition to the aforementioned, in theory, other specificities of cross-border cooperation were highlighted, such as the project promoters being non-profit legal entities that belonged to the following categories: organisations, institutions, chambers of commerce, regional and local authorities, regional development agencies, research and development centres, agricultural organisations, etc. Moreover, the cross-border character of the project had to be clearly visible, as well as a positive impact on both sides of the border (Algebra University College, 2017).

In the field of cross-border cooperation, in the period 2007-2013 Serbia had the opportunity to participate in six cross-border cooperation programmes with the neighbouring countries as well as two aforementioned transnational programmes. Thanks to its geographical position, AP Vojvodina was able to participate in four cross-border cooperation programmes (with Hungary, Romania, Croatia and Bosnia and Herzegovina).

Relevant aspects of development and realisation of cross-border cooperation of AP Vojvodina in the period 2007-2013 will be presented in the text below.

\section{Methodology and data sources used}

The subject of the analysis in the paper is the relevant aspects of development and realisation of cross-border cooperation of AP Vojvodina in the period 2007-2013. The method of theoretical content analysis with the basic methods of concretisation and specialisation, as well as the analytical-deductive method of data analysis, has been primarily applied in the paper. 
In addition to the analysis of the cross-border cooperation of AP Vojvodina in the IPA programme implementation period, in the part of the paper that will sublimate the results of the subject analysis, an overview will be also made of the possibility of using pre-accession assistance for the period 2014-2020 within the IPA II programme.

\section{Research results and discussion}

Starting from the fact that Serbia did not have an accredited decentralised EU fund management system in the past period, and that it could not independently manage the EU funds, which implied the possibility of using only the first two IPA components (transition support and institution building and cross-border cooperation), during the period 2007-2013, the Republic of Serbia was given approximately EUR 1.4 billion of grants, of the total EUR 11.468 billion that the IPA programme implied and defined for the support of the countries in the process of EU accession (Group of authors, 2016).

The participation of AP Vojvodina in the funds defined by the IPA programme can best be seen in the field of cross-border cooperation (other IPA components).

Thanks to its geographical position, AP Vojvodina was able to participate in four crossborder cooperation programmes (with Hungary, Romania, Croatia and Bosnia and Herzegovina), financed from another IPA component.

As stated in the document called AP Vojvodina Development Program 20142020, that during the three calls for proposals within the Cross-border Cooperation Programme with Hungary, entities from the territory of AP Vojvodina attracted about EUR 21,695,257. In two calls with Romania, entities from Vojvodina attracted about EUR 10,294,398. Then, in the first call with the Croatian entities from the territory of Vojvodina, EUR 1,301,754 was approved (it should be noted that two public invitations were announced in the Cross-border Cooperation Program between Croatia and Serbia, but the authors at the time of writing the paper had only data for the first call, and accordingly, the values of donations to project partners from Vojvodina were shown less than real values), while in two calls with Bosnia and Herzegovina, entities from AP Vojvodina were approved EUR 167,372 (Group of authors, 2016).

The first table below shows the funds identified by the IPA programme for the implementation of the first two IPA components in Serbia in the period 2007-2013, showing the values of the percentage share of total assets allocated for Serbia in the overall assets foreseen by the IPA programme.

The second table then shows the reference values of AP Vojvodina's participation in four cross-border cooperation projects with the applicative analysis of the comparative values of each cross-border project, with a special overview of the percentage share of the realised assets in AP Vojvodina for each cross-border project in relation to the total IPA assets allocated for the Republic of Serbia, for the period 2007-2013, and defined for the second component. 
Table 1. IPA programme identified assets for implementation of the first component transition support and institution building, and other component - cross-border cooperation, in Serbia in the period 2007-2013.

\begin{tabular}{|c|c|c|c|c|c|c|}
\hline 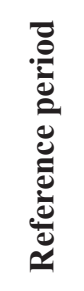 & 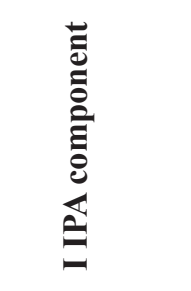 & 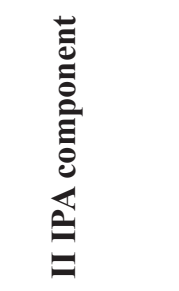 & 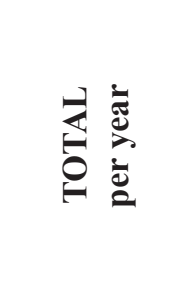 & 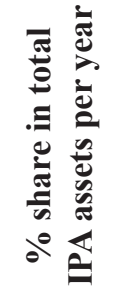 & 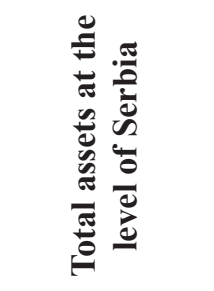 & 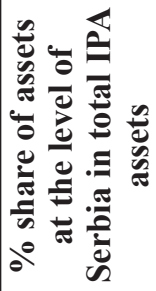 \\
\hline 2007 & $181,496,352$ & $8,203,648$ & $189,700,000$ & $1.65 \%$ & \multirow{7}{*}{$1,395,868,923$} & \multirow{7}{*}{$12.17 \%$} \\
\hline 2008 & $179,441,314$ & $11,458,686$ & $190,900,000$ & $1.66 \%$ & & \\
\hline 2009 & $182,551,643$ & $12,248,357$ & $194,800,000$ & $1.70 \%$ & & \\
\hline 2010 & $186,206,679$ & $11,751,753$ & $197,958,432$ & $1.73 \%$ & & \\
\hline 2011 & $189,956,810$ & $11,922,790$ & $201,879,600$ & $1.76 \%$ & & \\
\hline 2012 & $193,801,948$ & $12,097,244$ & $205,899,192$ & $1.80 \%$ & & \\
\hline 2013 & $203,101,005$ & $11,630,694$ & $214,731,699$ & $1.87 \%$ & & \\
\hline
\end{tabular}

Source: Group of authors, 2016, p. 196.

Note: Percentage values: author's calculation.

Having in mind the presented data, it can be noted that the amount of assets identified from the IPA programme for the implementation of the first two IPA components transition support and institution building and cross-border cooperation in the Republic of Serbia, in the period 2007-2013, increased proportionally, which is confirmed by the perception of the percentage share of total assets per year at the level of Serbia in the total assets of the IPA programme.

Considering the percentage share of the total assets defined in the IPA Programme for the Republic of Serbia for the entire period (total assets: EUR 1,395,868,923), compared to the total assets available to the IPA programme (total IPA assets: EUR 11,468,000,000), it can be noted that $12.17 \%$ of the total assets of the IPA programme were defined for the whole period for the Republic of Serbia, which is a significant amount of assets allocated to support the economic and social transformation of a country that is in the process of accession to the European Union. In doing so, we should not lose sight of the fact that Serbia had the opportunity to use only the first two IPA components (out of a total of five that the IPA programme has foreseen).

In the context of the data presented in the following table, it should be noted that the percentage share of the IPA assets allocated for the implementation of the second component (cross-border cooperation) in Serbia in the period 2007-2013, in relation to the total IPA assets allocated for Serbia in the mentioned period, is $0.7 \%$, which is significantly less compared to the percentage share of the IPA assets allocated for the implementation of the first component in Serbia in the same period $(11.48 \%)$. 
Table 2. The reference values of AP Vojvodina's participation in four cross-border cooperation projects - Hungary-Serbia, Romania-Serbia, Croatia-Serbia and Bosnia-Herzegovina-Serbia, in the period 2007-2013

\begin{tabular}{|c|c|c|c|c|}
\hline \multicolumn{5}{|c|}{$\begin{array}{c}\text { II IPA component - Cross-border cooperation } \\
2007-2013\end{array}$} \\
\hline & $\begin{array}{l}\text { Hungary - } \\
\text { Serbia }\end{array}$ & $\begin{array}{l}\text { Romania - } \\
\text { Serbia }\end{array}$ & $\begin{array}{c}\text { Croatia - } \\
\text { Serbia }\end{array}$ & $\begin{array}{c}\text { Bosnia and } \\
\text { Herzegovina } \\
\text { - Serbia }\end{array}$ \\
\hline $\begin{array}{l}\text { Total realised assets } \\
\text { in AP Vojvodina }\end{array}$ & 21,695,257 EUR & 10,294,398 EUR & 1,301,754 EUR & 167,372 EUR \\
\hline $\begin{array}{c}\% \text { share of APV } \\
\text { assets in total IPA } \\
\text { assets for Serbia, for } \\
\text { II component } \\
(79,313,172 \text { EUR })\end{array}$ & $27.35 \%$ & $12.98 \%$ & $1.64 \%$ & $0.21 \%$ \\
\hline $\begin{array}{c}\text { Total projects in AP } \\
\text { Vojvodina }\end{array}$ & 198 & 59 & 11 & 2 \\
\hline $\begin{array}{l}\text { Territory covered by } \\
\text { the programme } \\
\text { (districts) in AP } \\
\text { Vojvodina }\end{array}$ & $\begin{array}{c}\text { West Bačka } \\
\text { district, North } \\
\text { Bačka district, } \\
\text { North Banat } \\
\text { district, South } \\
\text { Banat district, } \\
\text { Central Banat } \\
\text { district (South } \\
\text { Banat district } \\
\text { and Srem district } \\
\text { are the joined } \\
\text { regions) }\end{array}$ & $\begin{array}{c}\text { North Banat } \\
\text { district, Central } \\
\text { Banat district, } \\
\text { South Banat } \\
\text { district }\end{array}$ & $\begin{array}{l}\text { North Bačka } \\
\text { district, South } \\
\text { Bačka district, } \\
\text { West Bačka } \\
\text { district }\end{array}$ & $\begin{array}{l}\text { South Bačka } \\
\text { district, Srem } \\
\text { district }\end{array}$ \\
\hline $\begin{array}{l}\text { Counties / Regions } \\
\text { in the partner state: }\end{array}$ & $\begin{array}{l}\text { Čongrad and } \\
\text { Bač-Kiškun }\end{array}$ & $\begin{array}{l}\text { Timis, Caras- } \\
\text { Severin and } \\
\text { Mehedinti }\end{array}$ & $\begin{array}{l}\text { Osijek-Baranja, } \\
\text { Vukovar- } \\
\text { Srijem, Požega- } \\
\text { Slavonia and } \\
\text { Brod-Posavina } \\
\text { counties }\end{array}$ & $\begin{array}{l}\text { Sarajevo } \\
\text { economic } \\
\text { region and } \\
\text { Southeast } \\
\text { economic } \\
\text { region } \\
\end{array}$ \\
\hline $\begin{array}{c}\text { District in AP } \\
\text { Vojvodina with the } \\
\text { most attracted assets } \\
\text { and applicants }\end{array}$ & $\begin{array}{c}\text { South Bačka } \\
\text { district } \\
(11,713,381 \\
\text { EUR; } \\
107 \text { applicants })\end{array}$ & $\begin{array}{c}\text { South Banat } \\
\text { district } \\
(3,680,873 \text { EUR; } \\
19 \text { applicants })\end{array}$ & $\begin{array}{c}\text { South Bačka } \\
\text { district } \\
\text { (801,063 EUR; } \\
6 \text { applicants) }\end{array}$ & $\begin{array}{l}\text { Srem district } \\
(104,686 \\
\text { EUR; } \\
1 \text { applicant })\end{array}$ \\
\hline $\begin{array}{l}\text { District in AP } \\
\text { Vojvodina with the } \\
\text { fewest attracted } \\
\text { assets and applicants }\end{array}$ & $\begin{array}{l}\text { South Banat } \\
\text { district } \\
(35,700 \text { EUR; } \\
1 \text { applicant })\end{array}$ & $\begin{array}{l}\text { North Banat } \\
\text { district } \\
\text { (204,754 EUR; } \\
3 \text { applicants) }\end{array}$ & $\begin{array}{c}\text { West Bačka } \\
\text { district } \\
\text { (190,110 EUR; } \\
1 \text { applicant) }\end{array}$ & $\begin{array}{c}\text { South Bačka } \\
\text { district } \\
\text { (62,687 EUR; } \\
1 \text { applicant) }\end{array}$ \\
\hline
\end{tabular}




\begin{tabular}{|c|c|c|c|c|}
\hline \multicolumn{5}{|c|}{$\begin{array}{l}\text { II IPA component - Cross-border cooperation } \\
2007-2013\end{array}$} \\
\hline & $\begin{array}{l}\text { Hungary - } \\
\text { Serbia }\end{array}$ & $\begin{array}{l}\text { Romania - } \\
\text { Serbia }\end{array}$ & $\begin{array}{l}\text { Croatia - } \\
\text { Serbia }\end{array}$ & \begin{tabular}{|c|} 
Bosnia and \\
Herzegovina \\
- Serbia \\
\end{tabular} \\
\hline $\begin{array}{l}\text { Cross-border project } \\
\text { priorities }\end{array}$ & $\begin{array}{l}\text { 1.) Infrastructure } \\
\text { and environment; } \\
\text { 2.) Economy, } \\
\text { education and } \\
\text { culture; } \\
\text { 3.) Technical } \\
\text { assistance }\end{array}$ & $\begin{array}{l}\text { 1.) Economic } \\
\text { and social } \\
\text { development; } \\
\text { 2.) Environmental } \\
\text { protection and } \\
\text { emergency } \\
\text { preparedness; } \\
\text { 3.) Promoting } \\
\text { the "people } \\
\text { to people" } \\
\text { exchange; } \\
\text { 4.) Technical } \\
\text { assistance }\end{array}$ & $\begin{array}{l}\text { 1.) Sustainable } \\
\text { socio-economic } \\
\text { development; } \\
\text { 2.) Technical } \\
\text { assistance }\end{array}$ & $\begin{array}{l}\text { 1.) Social and } \\
\text { economic } \\
\text { cohesion } \\
\text { through } \\
\text { activities } \\
\text { for the } \\
\text { improvement } \\
\text { of physical, } \\
\text { business, } \\
\text { social and } \\
\text { institutional } \\
\text { infrastructure } \\
\text { and } \\
\text { capacities; } \\
\text { 2.) Technical } \\
\text { assistance }\end{array}$ \\
\hline
\end{tabular}

Source: Group of authors, 2016, p. 197-202; Pejović et al., 2011, p. 59-72.

Note: Percentage values: author's calculation.

Having in mind the available data, it is concluded that in the period 2007-2013, the highest amount of assets and the most projects were realised in the cross-border cooperation between Hungary and Serbia (EUR 21,695,257 and 198 projects).

The districts from the territory of AP Vojvodina with the most attracted assets and applicants are: South Bačka district from cross-border cooperation Hungary - Serbia (EUR 11,713,381 and 107 applicants) and South Banat district from cross-border cooperation Romania-Serbia (EUR 3,680,873 and 19 applicants).

The districts from the territory of AP Vojvodina with the fewest attracted assets and applicants are the following: South Banat district from cross-border cooperation Hungary - Serbia (EUR 35,700 and 1 applicant) and South Bačka district from crossborder cooperation Bosnia and Herzegovina - Serbia (EUR 62,687 and 1 applicant).

The percentage share of assets realised in AP Vojvodina for each cross-border project in relation to the total assets allocated for the Republic of Serbia for the period 2007-2013, and defined for the second component, is shown in the following way: cross-border cooperation Hungary - Serbia: 27.35\%; cross-border cooperation Romania - Serbia: 12.98\%; cross-border cooperation Croatia - Serbia: $1.64 \%$; cross-border cooperation Bosnia and Herzegovina - Serbia: $0.21 \%$. 


\section{Conclusion}

The current definition of the regional policy of the European Union, stated in the Europe 2020 Strategy, highlights the importance of this programme for the candidate countries as well as the neighbouring countries, stating that the enlargement of the space where European Union rules apply will create new opportunities both for the European Union and for its neighbours, encouraging a balanced and sustainable development as a presumption of stability.

For the period 2014-2020, the European Commission has created a new Instrument for PreAccession Assistance (IPA II), with the aim of closer connection with the EU enlargement priorities, aimed at achieving results and a strategic approach to key reforms in the candidate countries and potential candidates for EU membership (Pejović et al., 2014).

The IPA II programme contains a variety of differences compared to the previous IPA programme for the period 2007-2013. One of the major changes relates to the structure of the IPA II programme, in which, instead of the existing five components that were characteristic for IPA, the so-called policy areas have been introduced. Policy areas within IPA II are: reforms as part of preparations for EU membership and institution and capacity building; socio-economic and regional development; employment, social policy, education, promotion of gender equality and human resources development; agriculture and rural development; regional and territorial cooperation. These policy areas are very similar in content to the IPA components and are now available to all beneficiary countries regardless of their status in the European integration process (candidates or potential candidates for EU membership) (Pejović et al., 2014).

Total IPA II budget for the period 2014-2020 amounts to EUR 11.7 billion. Indicative allocation of IPA II to assistance beneficiaries 2014-2020 for the Republic of Serbia, amounts to EUR $1,508,000,000$ (Pejović et al., 2014), which accounts for $12.89 \%$ of the total IPA II assets, and confirms the commitment of the IPA II programme to continue its assistance to cross-border cooperation programmes between candidate countries and potential candidates, as well as between them and the EU Member States that they border with.

As for the area of pre-accession assistance, after years of experience in the use of the available components of the IPA programme, the AP Vojvodina Regional Development Framework sets out the following main challenges for acquiring the possibility of using pre-accession assistance for the period 2014-2020 (IPA II): insufficient level of high-quality strategic framework, unwillingness of urban and project-technical documentation for infrastructure projects, unresolved property relations, pre-financing and co-financing of projects, and sustainability of administrative capacities (Group of authors, 2016). The same document points out "recommendations such as active participation in programming and monitoring of international development assistance, strengthening of human capacities, development of urban, planning and projecttechnical documentation, and establishing of mechanism for co-financing and prefinancing projects," (Group of authors, 2016) as key conditions for further use of international development assistance funds. 


\section{Acknowledgements}

This paper is the result of research within the project "Analysis of the normative framework and practice of cross-border cooperation of the Autonomous Province of Vojvodina as a determinant of sustainable development" (no. 142-451-2696/2017-01), Provincial Secretariat for Higher Education and Scientific Research.

\section{Conflict of interests}

The authors declare no conflict of interest.

\section{References}

1. Algebra University College, Basic information on EU funds, (available at: http://algebra.hr/.../Osnovne-informacije-o-EU-fondovima.pdf, 11.11.2017).

2. European Commission (2014): European Union policies: Regional policy, Publications Office of the European Union, Luxembourg.

3. European Commission (2011): Cohesion policy 2014-2020 - investment in growth and employment, Publications Office of the European Union, Luxembourg.

4. European Commission, Directorate-General for Regional and Urban Policy, Regional Policy, European Structural and Investment Funds, (available at: http://ec.europa.eu/regional policy/en/funding/, 10.11.2017).

5. Europe 2020 - A strategy for smart, sustainable and inclusive growth, European Commission, Communication from the Commission COM (2010) 2020, Brussels 2010.

6. Golić, D., Počuča, S. (2017): Decentralized and delegated affairs of a state administration in the field of Agriculture, Economics of Agriculture, vol. 64, No. 2, 769-785, Institute of Agricultural Economics, Belgrade, The Republic of Serbia.

7. Group of authors (2016): AP Vojvodina development programme 20142020, (available at: http://programrazvoja.vojvodina.gov.rs/wp-content/ uploads/2016/03/Program_razvoja_AP_Vojvodine_2014_2020_3891.pdf, 13.11.2017).

8. Kačar, B., Curić, J., Ikić, S. (2016): Local economic development in theories of regional economies and rural studies, Economics of Agriculture, vol. 63, No. 1, 231-246, Institute of Agricultural Economics, Belgrade, The Republic of Serbia.

9. Komšić, J. (2007): European regionalism principles, Association of Multiethnic Cities of Southeast Europe- Philia, Novi Sad, Republic of Serbia.

10. Kronja, J. (2015): Europe 2020 Strategy: four years later, European Movement in Serbia, Belgrade, Republic of Serbia. 
11. Međak, V., Majstorović, S. (2004): Regional policy of the European Union, EU Accession Office, Belgrade, Republic of Serbia.

12. Mirić, O. (2014): Analysis of the impact of the process of Serbia's accession to the European Union on local governments - area of regional (cohesion) policy of the European Union, "Support to Local Self-Governments in Serbia in the Process of European Integration" programme, Standing Conference of Cities and Municipalities, Belgrade, Republic of Serbia.

13. Mirić, O. (2009): Regional policy of the European Union as an engine of economic development, European Movement in Serbia, Belgrade, Republic of Serbia.

14. Pejović, A., Živadinović, B., Lazarević, G., Knežević, I., Lazović, M., Mirić, O. (2011): Instrument for EU Pre-Accession Assistance 2007-2013, European Movement in Serbia, Belgrade, Republic of Serbia.

15. Pejović, A., Lazović, M., Mirić, O., Knežević, I. (2014): Guide for IPA II Instrument for Pre-Accession Assistance 2014-2020, European Movement in Serbia, Belgrade, Republic of Serbia.

16. Regional Development, Regional Development Policy of the European Union, (available at: http:/www.regionalnirazvoj.gov.rs/Lat/ShowNARRFolder. aspx?mi=27, 12.11.2017).

17. Vuković, D., Jovanović, A., Grubišić, Z. (2012): The economic aspect of the regionalisation of European countries, Journal of the Geographical Institute "Jovan Cvijić", vol. 62, no. 1, p. 31-48, Geographical Institute "Jovan Cvijić" Serbian Academy of Sciences and Arts, Republic of Serbia. 